\title{
Mide ve Kolorektal Kanserli Hastalarda Serum Sistatin C Düzeyi ve CEA, CA 19-9 ile İlişkisinin İncelenmesi
}

\section{Evaluation of Serum Cystatin C Levels And Its Relation with CEA, CA 19-9 in Patients with Gastric and Colorectal Cancer}

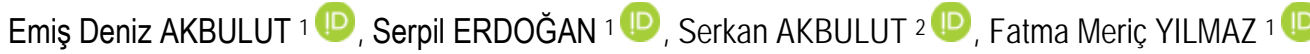 \\ 1 Ankara Numune Eğitim ve Araştırma Hastanesi, Tıbbi Biyokimya Laboratuvarı, Ankara, Türkiye \\ 2 Ankara Numune Eğitim ve Araştırma Hastanesi, Genel Cerrahi Kliniği, Ankara, Türkiye
}

öz.

Amaç: Böbrek fonksiyonun bir belirteci olarak bilinen sistatin C'nin tümör gelişiminde inhibör etki gösterdiği düşünülmektedir. Çalışmada bilinen böbrek hastalığı olmayan mide ve kolorektal kanserli olgularla sağlıkı bireylerin serum sistatin $C$ düzeyleri arasındaki olası farkın, serum karsinoembriyonik antijen (CEA) ve karbohidrat antijen 19-9 (CA19-9) düzeyleri arasındaki ilişkinin incelenmesi amaçlanmıştır.

Materyal ve metod: Çalışmaya serum kreatinin konsantrasyonu referans aralığı içerisinde yer alan ve tahmini glomerüler filtrasyon hızı (eGFH) $>60 \mathrm{~mL} / \mathrm{dk}$ olan mide $(n=35)$ ve kolorektal kanserli $(n=35)$ hastalar ile bilinen herhangi bir sistemik hastalığı olmayan sağlıkı bireyler $(n=40)$ dahil edilmiştir. CEA ve CA 19-9 testleri kemilüminesans temelli immün yöntemle (Beckman Coulter UniCel@ Dxl 800 Immunoassay System) Sistatin C analizi ise partikül yüzeyi genişletilmiş immünotürbidimetrik yöntem (Roche Diagnostics Cobas ${ }^{\circledR}$ Modular $\mathrm{P}^{\circledR}$ ) kullanılarak yapılımıştır.

Bulgular: Mide, KRK (kolorektal kanser) ve kontrol grupları arasında serum kreatinin konsantrasyonu açısından önemli fark izlenmezken $(p=0,571)$ sistatin $C$ düzeyi hasta gruplarında kontrol grubuna göre anlamlı olarak daha yüksek izlenmiştir $(p<0,001)$. Çoklu değişkenli lojistik regresyon analizinde sistatin $C$ düzeyinin yüksek olması üzerinde sırasıyla; kreatinin düzeyi ve kanser hastası olmanın etkili olduğu bulunmuştur. Kreatinindeki her $0,1 \mathrm{mg} / \mathrm{dL}$ 'lik artış sistatin C düzeyinin yüksek olma intimalini 2,531 kat (\%95 güven aralığı: 1,562-4,100) arttırmaktadır $(p<0,001)$. Ayrıca kontrol grubuna göre kanserli grupta sistatin C'nin yüksek olma ihtimalinin 20,384 kat (\%95 güven aralığı: 2,992$142,196)$ fazla olduğu bulunmuştur $(p=0,002)$. Hasta grubunda yer almak, yaş, cinsiyet ve kreatinin konsantrasyonu gibi faktörlerin etkileri göz önünde bulundurulduğunda CEA ve CA 19-9 yüksekliği ile serum sistatin C düzeyi arasında anlamlı ilişki izlenmemiştir $(p>0,05)$.

Sonuç: Mide veya kolorektal kanserli olgularda serum sistatin C düzeyinin böbrek fonksiyonunun yanısıra kanser varlığından da etkilenebileceği gözlenmiştir.

Anahtar Kelimeler: Sistatin C, Katepsin, Mide Kanseri, Kolorektal Kanser

Abstract

Background: Cystatin C, a marker of kidney function, is thought to have inhibiting effects in tumor growth. In the study comparing serum concentrations of cystatin $\mathrm{C}$ among gastric, colorectal cancer patients, controls and determination of its relation between serum CEA and CA 19-9 levels are aimed.

Materials and Methods: Gastric cancer patients $(n=35)$, colorectal cancer patients $(n=35)$ and healthy subjects $(n=40)$ without any known systemic disease were included in the study. None of the participants had previously known kidney disease, serum creatinine level out of reference interval or eGFR $60 \mathrm{~mL} / \mathrm{min}$. Serum CEA and CA 19-9 levels were

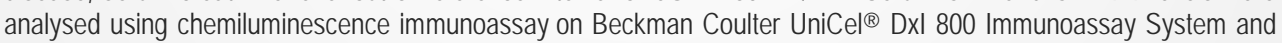
cystatin C was analysed with particle-enhanced turbidimetric immunoassay on Roche Diagnostics Cobas ${ }^{\circledR}$ Modular $\mathrm{P}^{\circledR}$ analyzer.

Results: Cystatin C levels were significantly higher in patients' sera $(p<0.001)$ while there was no significant difference between groups for serum creatinine $(p=0.571)$. Multivariate logistic regression analysis revealed that creatinine level and participation in the patient groups were the determinants of the elevated serum cystatin $\mathrm{C}$ concentration, respectively. Each $0.1 \mathrm{mg} / \mathrm{dL}$ elevation in creatinine level increased the possibility of having high cystatin C level 2.531 times (95\% Cl: 1.562-4.100). Besides the possibility of finding high cystatin C levels were 20.384 times more in the patient group (95\% Cl:2.992-142.196). No significant relation between CEA, CA 19-9 and cystatin C was observed when participation in patient groups, age, sex and creatinine concentration were taken into consideration ( $p>0.05)$.

Conclusion: Serum cystatin C concentrations of gastric and colorectal cancer patients may be affected due to the presence of cancer besides kidney function.

Key words: Cystatin C, Cathepsin, Gastric Cancer, Colorectal Cancer

\section{Sorumlu Yazar I \\ Corresponding Author}

Emiş Deniz AKBULUT

Ankara Şehir Hastanesi

Üniversiteler mahallesi,

1604.cadde, no:9, MHC Blok,

Biyokimya Laboratuvarı, 06800,

Çankaya/ANKARA

\section{Tel: 05057484294 \\ e-mail: denizatagun@hotmail.com}

Geliş tarihi / Received:

17.02.2020

Kabul tarihi / Accepted:

09.11 .2020

DOI: 10.35440/hutfd.689952 


\section{Giriş}

Kanser, ülkemizde ve dünyada ölüm nedenleri arasında ikinci sırada yer alması nedeniyle önemli bir halk sağığı sorunudur. Dünya Sağlık Örgütü'nün 2018 yılı verilerine göre kolorektal kanser (KRK) ve mide kanseri görülme sıklığında sırasıyla üçüncü ve altıncı sırada yer almaktadır. Kansere bağlı ölüm nedeni sıralamasında ise KRK ikinci sırada yer alırken onu mide kanseri izlemektedir (1).

Tümör hücrelerinde artmış katepsin üretimi ve salınımının tümör gelişimine, invazyonuna ve metastazına öncülük ettiği bilinmektedir $(2,3)$. Katalitik mekanizmalarına göre katepsinler; serin (A ve G), sistein (B, C, F, H, K, L, O, S, V, $W$ ve $X$ ) ve aspartik ( $D$ ve $E$ ) proteazlar olarak sınıflandırlIırlar (4). Böbrek fonksiyonunun endojen bir belirteci olan sistatin C (5) sistein proteazların önemli bir fizyolojik inhibitörüdür (3). Neoplastik dokunun eksprese ettiği katepsin/sistatin oranının, tümör davranışını belirlemede önemli olduğu bildirilmiştir (6). Mide kanseri ve KRK' de tümör dokusundaki katepsin B ekspresyonundaki artışın tümör progresyonu ile ilişkili olduğu saptanmıştır (3). İmmünhistokimyasal olarak gastrik (7) ve kolorektal kanser (8) hücrelerinde normal hücrelere göre artmış sistatin $C$ ekspresyonu izlenmiştir. Ayrıca KRK hastalarında katepsin B'nin serumdaki artışının da kötü prognoz göstergesi olduğu bildirilmiştir (9).

Hücre proliferasyonu, diferansiasyonu ve apoptozisin önemli bir düzenleyicisi olan "Dönüştürücü Büyüme Faktörü $\beta " n ı n$ (TGF- $\beta$ ) kanser progresyonu sırasında tümör üzerindeki süpresör etkisinin genellikle bozulduğu, tümör gelişimini ve metastazını uyardığı bilinmektedir. TGF- $\beta$ ekspresyonunun kolorektal ve gastrik kanserde arttığı gösterilmiştir (10). Sokol ve ark. sistatin C'nin tümör gelişimindeki inhibitör rolünün katepsin aracılı invazyon ve metastazı, katepsin B ile uyarılmış latent TGF- $\beta$ aktivasyonunu ve TGF- $\beta$ 'nın tip II reseptörüne (TRR-II) bağlanmasını önlemesi yolu ile gerçekleştiğini bildirmişlerdir (11).

Literatürde KRK hastalarında sistatin $C$ düzeyini serumda inceleyen az sayıda çalışma $(9,12)$ izlenmiş olup bu çalışmaların çeşitli kısıt|lııklarından bahsedilmiştir. Kanser hastalarında sistatin $\mathrm{C}$ düzeyinin böbrek fonksiyon belirteci olarak değerinin incelendiği bir çalışmada (13) mide kanserli hastalar küçük bir altgrup olarak dahil edilmiştir.

Preoperatif serum karsinoembriyonik antijen (CEA) ve karbohidrat antijen 19-9 (CA19-9) seviyeleri kolorektal kanser için prognoz tahmininde faydalıdır $(14,15)$. Mide kanserinde serum CEA ve CA 19-9 pozitifliği ile hastalığın prognozu arasında anlamlı bir ilişki olduğu bilinmektedir (16). Ayrıca over kanserli hastalarda serum sistatin $C$ düzeyi ile CA 125 arasında anlamlı korelasyon izlenmiştir (17).

$\mathrm{Bu}$ çalışmada serum kreatinin konsantrasyonu referans aralığı içinde olan ve tahmini glomerüler filtrasyon hızı (eGFH) $>60 \mathrm{~mL} / \mathrm{dk}$ olan mide ve kolorektal kanser hastalarında serum sistatin $C$ düzeyleri ile gastrointestinal sistem kanserlerinde kullanılan başlıca tümör belirteçleri (CEA ve
CA 19-9) arasındaki ilişkinin incelenmesi amaçlanmıştır.

\section{Materyal ve Metod}

Çalışmaya üçüncü basamak bir eğitim ve araştırma hastanesi genel cerrahi kliniğine başvuran, endoskopik biyopsi sonuçlarına göre mide kanseri $(n=35)$ veya KRK $(n=35)$ tanısı konulmuş hastalar ve kontrol grubu olarak ise bilinen herhangi bir sistemik hastalığı olmayan sağlıklı bireyler $(n=40)$ dahil edilmiştir. Bilinen böbrek hastalığı olan, serum kreatinin konsantrasyonu referans aralığı (erkek için; 0,64$1,27 \mathrm{mg} / \mathrm{dL}$, kadın için; 0,44-1,03 mg/dL) dışında ya da eGFH değeri $60 \mathrm{~mL} / \mathrm{dk}$ 'dan küçük olan olgular çalışma dışında bırakıldı. Bilinen tiroid disfonksiyonu, hipertansiyon, diabetes mellitus, koroner arter hastalığı, santral sinir sistemi hastalı̆̆ı, romatolojik hastalığı veya başka kronik hastalığı olan hastaların örnekleri dahil edilmedi. Çalışma için kurumun etik kurulundan onay alınmıştır (T.C. Sağlık Bakanlığı Ankara Numune Eğitim ve Araştırma Hastanesi'nin 25/01/2012 tarih ve 2012-302 numaralı etik kurul kararı). Kreatinin testi için Beckman Coulter DxC 800 otoanalizörü, CEA ve CA 19-9 testleri için Beckman Coulter UniCel ${ }^{\circ}$ DxI 800 Immunoassay Systemde aynı marka kitler kullanılarak çalışıldı. Sistatin C testi için ise alınan kan örneklerinin serumları daha sonra çalışılmak üzere ayrılarak ağzı kapaklı tüplerde $-80^{\circ} \mathrm{C}$ 'de saklandı. Serum sistatin $\mathrm{C}$ analizi Roche Diagnostics Cobas ${ }^{\circledR}$ Tina-quant Cystatin $\mathrm{C}$ kiti kullanılarak Roche MODULAR $\mathrm{P}^{\circledR}$ analizöründe partikül yüzeyi genişletilmiş immünotürbidimetrik yöntem (PETIA) ile yapıldı.

Verilerin analizi SPSS for Windows 11.5 paket programında yapıldı. Sürekli değişkenlerin dağılımının normale yakın olup olmadığı Shapiro Wilk testiyle varyansların homojenliği ise Levene testiyle araştıııı I. Tanımlayıcı istatistikler sürekli değişkenler için ortalama \pm standart sapma veya ortanca (çeyrekler arası genişlik) olarak nominal değişkenler ise olgu sayısı ve (\%) şeklinde gösterildi.

Gruplar arasında ortalamalar yönünden farkın önemliliği bağımsız grup sayısı iki olduğunda Student's t testi ile ikiden fazla grup arasındaki farkın önemliliği ise Tek Yönlü Varyans Analizi (One-Way ANOVA) ile değerlendirildi. Gruplar arasında ortanca değerler yönünden farkın önemliliği bağımsız grup sayısı iki olduğunda Mann Whitney U testi ile ikiden fazla grup arasındaki farkın önemliliği ise Kruskal Wallis testi ile incelendi. Kruskal Wallis test istatistiği sonucunun önemli bulunması halinde farka neden olan durumları tespit etmek amacıyla Conover'in parametrik olmayan çoklu karşılaşııma testi kullanıldı. Nominal değişkenler Pearson'un Ki-Kare ya da Fisher'in Kesin Sonuçlu Ki-Kare testiyle değerlendirildi. Sürekli değişkenler arasında istatistiksel olarak anlamlı ilişki olup olmadığı Spearman'ın Korelasyon testiyle araştırıldı.

Sistatin $C$ düzeyi normal olan grup ile yüksek olan grubu ayırt etmede en fazla belirleyici olan faktörleri tespit etmek için Çoklu Değişkenli Lojistik Regresyon analizi kullanıldı. 
Tek değişkenli istatistiksel analizler sonucunda $p<0,25$ olarak saptanan değişkenler aday risk faktörleri olarak regresyon modeline dahil edildi. Ayrıca, her bir değişkene ait odds oranı ve $\% 95$ güven aralıkları hesaplandı. $p<0,05$ için sonuçlar istatistiksel olarak anlamlı kabul edildi.

\section{Bulgular}

Gruplar arasında yaş ve cinsiyet dağılımı açısından anlamlı fark izlenmemiştir (sırasıyla $p=0,505$ ve $p=0,510$ ). OIguların dahil oldukları gruplara göre demografik özellikleri Tablo 1'de özetlenmiştir.

Tablo 1. Kontrol ve Vaka Gruplarına Göre Olguların Demografik Özellikleri

\begin{tabular}{lllll}
\hline Değişkenler & $\begin{array}{l}\text { Kontrol } \\
(\mathbf{n}: 40)\end{array}$ & $\begin{array}{l}\text { Kolorektal } \\
(\mathbf{n}: 35)\end{array}$ & Mide (n:35) & $\begin{array}{l}\mathbf{p} \\
\text { değeri }\end{array}$ \\
\hline Yaş (ortalama & $57,8 \pm 6,6$ & $60,2 \pm 9,5$ & $58,7 \pm 9,8$ & 0,505 \\
\pm ss) & & & & 0,510 \\
\hline Cinsiyet & & & & \\
[n (\%)] & & & & \\
Erkek & $24(\% 60,0)$ & $21(\% 60,0)$ & $25(\% 71,4)$ & \\
Kadın & $16(\% 40,0)$ & $14(\% 40,0)$ & $10(\% 28,6)$ & \\
\hline ss: standart sapma & & & &
\end{tabular}

Kolorektal ve mide kanseri grubundaki bireylerin serum CEA, CA19-9 ve Sistatin C düzeyleri kontrol grubundaki bireylere göre anlamlı olarak daha yüksekti (hepsi için $p<0,001)$. Her 3 grupta da serum kreatinin konsantrasyonu benzerdi (Tablo 2). Mide kanseri ve KRK gruplarında serum sistatin $C$ düzeyi yüksek olan olguların sayısı anlamlı olarak daha yüksek bulunmuştur $(p<0,001)$. Kontrol grubunda ise serum sistatin $C$ düzeyi normal bulunan bireylerin sayısı daha fazladır $(p<0,001)$. Şekil 1'de Kontrol, Kolorektal ve Mide Gruplarına Göre Sistatin C Düzeylerinin Dağılımı gösterilmiştir. Şekil 2'deki grafikte serum sistatin C düzeyi normal ve yüksek olan gruplarda serum kreatinin düzeylerinin dağılımı gösterilmiştir.

Tablo 2. Kontrol ve Vaka Gruplarına Göre Olguların Ölçüm Sonuçları

\begin{tabular}{|c|c|c|c|c|}
\hline $\begin{array}{l}\text { Değişken- } \\
\text { ler }\end{array}$ & $\begin{array}{l}\text { Kontrol } \\
(\mathrm{n}: 40)\end{array}$ & $\begin{array}{l}\text { Kolorektal } \\
\text { (n:35) }\end{array}$ & Mide (n:35) & $p$ değeri \\
\hline $\begin{array}{l}\text { CEA } \\
(\mathrm{ng} / \mathrm{mL})^{*}\end{array}$ & $1,5(1,00)^{a, b}$ & $12,6(43,89)^{a}$ & $12,1(69,36)^{b}$ & $<0,001$ \\
\hline $\begin{array}{l}\text { CA 19-9 } \\
(\mathrm{U} / \mathrm{mL})^{*}\end{array}$ & $8,2(8,77)^{a, b}$ & $43,8(77,10)^{\mathrm{a}}$ & $\begin{array}{l}100,0 \\
(546,60)^{\mathrm{b}}\end{array}$ & $<0,001$ \\
\hline $\begin{array}{l}\text { Kreatinin } \\
(\mathrm{mg} / \mathrm{dL})^{\star \star}\end{array}$ & $0,85 \pm 0,15$ & $0,80 \pm 0,20$ & $0,82 \pm 0,17$ & 0,571 \\
\hline $\begin{array}{l}\text { Sistatin C } \\
(\mathrm{mg} / \mathrm{L})^{*}\end{array}$ & $0,9(0,15)^{a, b}$ & $1,2(0,30)^{a}$ & $1,2(0,28)^{b}$ & $<0,001$ \\
\hline Sistatin C & $6(\% 15,0)^{a, b}$ & $26(\% 74,3)^{a}$ & $24(\% 68,6)^{b}$ & $<0,001$ \\
\hline
\end{tabular}

$>1,1 \mathrm{mg} / \mathrm{L}$

*: Veriler normal dağııım göstermeyen CEA, CA 19-9 ve Sistatin C için ortanca (çeyrekler arası genişlik), **: normal dağılım gösteren kreatinin için ortalama $\pm s s$ olarak gösterildi.

Analitler için üretici firmaların bildirdiği üst limit değerleri (CEA:3ng/mL, CA199:35U/mL, sistatin C:1,1 mg/L) kullanıldı. Çalışmaya serum kreatinin değeri referans aralığı (erkekler için: 0,64-1,27 mg/dL kadınlar için: 0,44-1,03 mg/ dL) içerisinde olan olgular dahil edilmiştir.

a: Kontrol Grubu ile Kolorektal Grubu arasındaki fark istatistiksel olarak anlamlı $(p<0,001)$,

b: Kontrol Grubu ile Mide Grubu arasındaki fark istatistiksel olarak anlamlı $(p<0,001)$.
Serum CEA, CA 19-9 ve kreatinin düzeyleri ile sistatin C düzeyi arasında anlamlı korelasyon izlenmiş̧ir (sırasıyla $r=0,498, p<0,001$ ve $r=0,294, p=0,002$ ve $r=0,343$, $p<0,001)$.

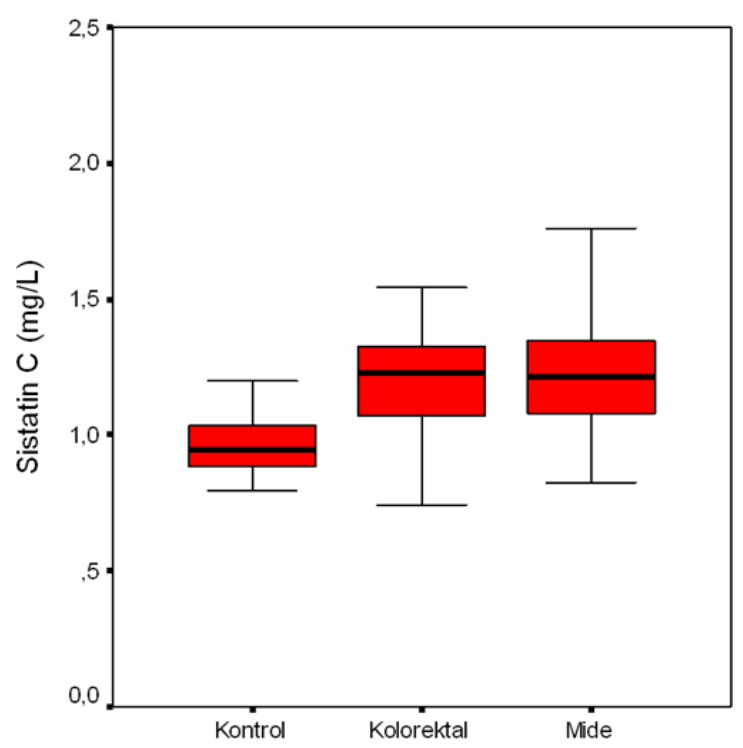

Şekil 1. Kontrol, Kolorektal ve Mide Gruplarına Göre Sistatin C Düzeylerinin Dağılımı

Diğer risk faktörlerine göre düzeltme yapıldığında sistatin $C$ düzeyinin yüksek olması üzerinde sırasıyla; kreatinin düzeyi ve kanser hastası olmanın etkili olduğu bulunmuştur. Buna göre kreatinindeki her $0,1 \mathrm{mg} / \mathrm{dL}$ 'lik artış sistatin $\mathrm{C}$ düzeyinin yüksek olma ihtimalini 2,531 kat (\%95 güven aralığı: $1,562-4,100)$ arttırmaktaydı $(p<0,001)$. Ayrıca kontrol grubuna göre kanserli grupta sistatin C'nin yüksek olma intimali 20,384 kat (\%95 güven aralı̆ıl: 2,992-142,196) daha fazla idi $(p=0,002)$.

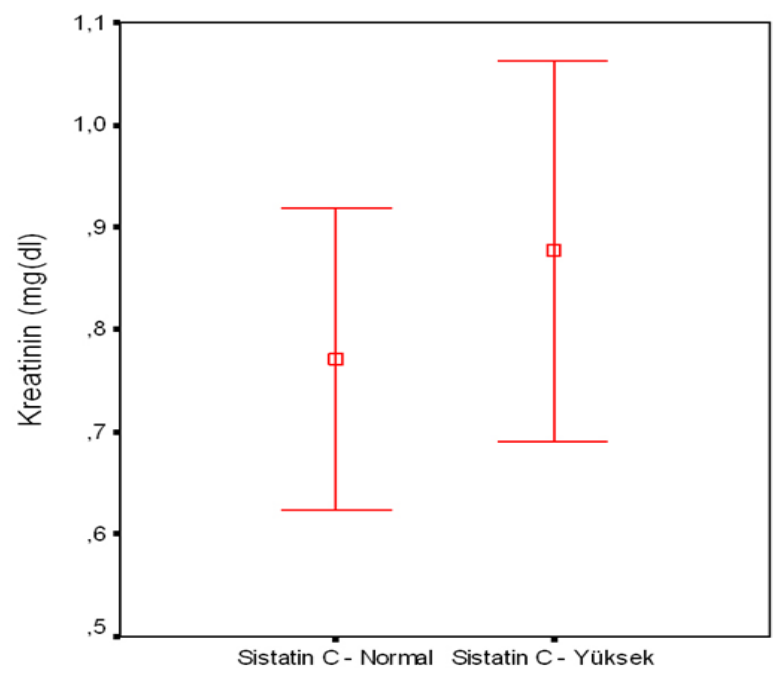

Şekil 2. Sistatin C Düzeyi Normal ve Yüksek Olan Gruplara Göre Kreatinin Düzeyleri 
Hasta grubuna dahil olmak, yaş, cinsiyet ve serum kreatinin konsantrasyonu gibi diğer faktörlerin etkileri de göz önünde bulundurulduğunda CEA ve CA $19-9$ yüksekliğinin daha önceki analizlerde izlenen anlamlı etkilerinin kaybolduğu görülmüştür $(p>0,05)$. Kontrol grubuna göre sistatin C'nin yüksek bulunma intimali üzerinde mide kanserli gruba göre KRK grubunda bulunmanın daha fazla etkili olduğu görülmüştür. Tablo 3'de çoklu değişkenli lojistik regresyon analizinin verileri özetlenmiştir.

Tablo 3. Çoklu Değişkenli Lojistik Regresyon Analizine Göre Sistatin C Düzeyi Normal ve Yüksek Olan Grupları Ayırt Etmede Etkili Olabilecek Olası Tüm Faktörlerin Birlikte Etkileri

\begin{tabular}{llll}
\hline Değişkenler & Odds Oranı & \%95 Güven Aralığı & p değeri \\
\hline Kolorektal & 23,979 & $3,213-178,962$ & 0,002 \\
Mide & 14,499 & $1,737-121,040$ & 0,014 \\
Yaş (yıl) & 1,036 & $0,975-1,101$ & 0,251 \\
Erkek Faktör & 0,475 & $0,122-1,842$ & 0,282 \\
CEA $>3$ ng/mL & 2,811 & $0,636-12,415$ & 0,173 \\
CA 19-9>35 U/mL & 1,199 & $0,290-4,955$ & 0,802 \\
Kreatinin (mg/dL) & $2,559 *$ & $1,571-4,170$ & $<0,001$ \\
\hline *: Kreatinin düzeyindeki her 0,1 mg/dL'lik artışın etkisi
\end{tabular}

\section{Tartışma}

Sistatin C, bütün çekirdekli hücrelerde sentezlenen düşük molekül ağırıklı (13 kDa) bir proteindir. Serum sistatin C konsantrasyonu glomerüler filtrasyon hızı ve böbrek fonksiyonunun bir belirteci olarak kabul görmektedir (5).

Sistatin C, endojen sistein proteazların fizyolojik olarak en önemli inhibitörüdür (3). Malign tümörlerde sistein katepsinler ile sistatin $\mathrm{C}$ arasındaki dengenin bozulduğu ve bunun kanser gelişim ve progresyonunda önemli basamaklar olan invazyon ve metastazı kolaylaştırdığı bildirilmiştir (18, 19). Sistein proteaz ailesinde yer alan bazı katepsinler ile sistatin C'nin mide kanseri ve KRK'de tümör dokusunda immünhistokimyasal olarak artmış ekspresyonu ve homojenizatlarında reverse transkriptaz-polimeraz zincir reaksiyonu (RT-PCR) ile artmış mRNA ekspresyonu olduğu gösterilmiştir. Mide kanseri ve KRK'de tümör dokusu ile yapılan çalışmalarda sistatin C'nin bu kanser türleri için iyi bir belirteç olabileceğini bildiren çalışmalar mevcuttur $(7,8)$. Bir analitin düzeyine serumda bakmak minimal invaziv olması, daha doğru kantifikasyon sağlaması ve gözlemciler arası fark içermemesi nedeniyle doku bazı ı metodlara göre daha avantajlıdır (20). Bu nedenle bu çalışmada serum sistatin $C$ düzeyleri açısından belirtilen kanser olguları ile kontrol grubu arasında anlamlı bir fark bulunup bulunmadığı ve kanser grupları arasında anlamlı bir fark izlenip izlenmediğinin araştırılması amaçlanmışıtır. Serum katepsin B konsantrasyonunun KRKde mevcut tümör belirteçleri CEA ve CA19-9'dan daha sensitif olduğu bildirilmiştir (21). Ayrıca over kanserli hastalarda serum sistatin $C$ düzeyi ile CA 125 arasında anlamlı korelasyon izlenmiştir (17). ÇaIışmanın bir diğer amacı da serum sistatin $C$ düzeyi ile gastrointestinal sistem kanserlerinde kullanılan başıca tümör belirteçleri CEA ve CA 19-9 konsantasyonları arasındaki ilişkinin incelenmesidir.
Kos ve ark. (12) ileri evre melanoma ve KRK hastalarında serum sistatin $C$ düzeyinin kontrol grubuna göre yüksek bulunduğunu bildirmişlerdir. Araştırmacılar vaka ve kontrol grupları arasında serum kreatinin düzeyi arasında anlamlı fark izlenmediğini belirtmiş, bu nedenle sistatin $\mathrm{C}$ düzeyinin kanser hastalarında böbrek dışı faktörler nedeniyle arttığı sonucuna varmışlardır. Çalışmamızda ise serum kreatinin konsantrasyonu açısından vaka ve kontrol grupları arasında anlamlı fark izlenmemekle birlikte sistatin $\mathrm{C}$ düzeyi yüksek olan olgularda serum kreatinin konsantrasyonu anlamlı olarak daha yüksek izlenmiştir. Diğer risk faktörlerine göre düzeltme yapıldığında sistatin $C$ düzeyinin yüksek olması üzerinde sırasıyla; kreatinin düzeyi ve kanser hastası olmanın etkili olduğu bulunmuştur. Ancak GFH tayini için referans bir yöntemin kullanılamamış olması çalışmamızın bir dezavantajıdır.

Literatürde kanser hastalarında sistatin C'nin çeşitli böbrek fonksiyon belirteçleriyle ilişkisini araştıran çalışmaların sonuçları tartışmalıdır $(22,23)$. Bunun nedeni hasta populasyonlarının farklı kriterlerle seçilmiş olması, analitlerin ölçümünde kullanılan yöntemlerin farklıı̆̆ı veya böbrek işlevi dışında diğer faktörlerden etkilenme olabilir. Serum sistatin $C$ değerinin böbrek fonksiyonu yanısıra kanser varlığından etkileniyor olması kanserli hastalarda kullanımı açısından bir dezavantaj olabilir.

KRK'li hastalarla yapılan bir çalışmada (24) serum sistatin $C$ yüksekliği ile yaş ve cinsiyet arasında ilişki izlenmemiş, ancak vaka grubunda sistatin $C$ ve yaş arasında zayıf bir korelasyon izlenmiştir. Vaka grubunun medyan yaş değeri [68(35-91)], kontrol grubununkinden [40(19-59)] yüksek bulunduğundan sistatin C'deki yüksekliğin yaşla ilişkili olarak GFH'deki azalmaya bağlı olabileceği yorumu yapılmıştır. Bizim çalışmamızda hasta $(59,5 \pm 9,6)$ ve kontrol grubunun $(57,8 \pm 6,6)$ yaş dağııımları arasında anlamlı bir fark yoktu ( $p=0,296)$. Serum sistatin $C$ düzeyi ile yaş arasında anlamlı bir korelasyon gözlenmedi $(r=0,126, p=0,190)$. $B u$ bulgu literatürde bildirilenleri $(25,26)$ destekler niteliktedir. Serum kreatinin ve sistatin $C$ konsantrasyonları arasında pozitif yönde bir korelasyon izlenmekte $(r=0,343, p<0,001)$ ve regresyon analizinde bu ilişki devam etmekteydi ( Tablo 3).

Melanomu olan hastalarda serum sistatin C konsantrasyonu ile hastalık evresi arasında anlamlı bir korelasyon bulunmuş; en yüksek seviyelere metastazı olan hastalarda rastlanmıştır (27). Kos ve ark. (24) KRK'li hastaların serumlarında tümör progresyonu ve kötü prognozla ilişkili artmış sistein proteaz inhibitörü konsantrasyonları izlemişlerdir. İnhibitörler arasında konsantrasyonda en belirgin artış sistatin C'de gözlenmiştir. Bazı araştırmacılar $(28,29)$ elde ettikleri bulgular ışığında serum sistatin $\mathrm{C}$ düzeyinin KRK gibi bazı kanser türlerinde tanı ve prognoz belirteci olabileceğini öne sürmüşlerdir.

Bizim çalışmamızda da kolorektal ve mide kanseri grubun- 
daki bireylerin serum sistatin $\mathrm{C}$ düzeyleri kontrol grubundaki bireylere göre anlamlı olarak daha yüksekti $(p<0,001)$. Analitin mide ve kolorektal grubundaki düzeyleri benzer bulundu. Sistatin $C$ yüksekliği kanserli gruba dahil olma ile birliktelik göstermekteydi. Sistatin C düzeyi yüksek olan olguların \%89,3'ü ( $n=50$ ) kanser hastası iken sistatin $C$ düzeyi normal bulunan olguların \%37,0'si $(n=20)$ kanserli gruba dahildi $(p<0,001)$. Diğer risk faktörlerine göre düzeltme yapıldığında kontrol grubuna göre kanserli grupta sistatin C'nin yüksek olma intimali 20,384 kat (\%95 güven aralığı: 2,992-142,196) daha fazla idi $(p=0,002)$. Sistatin C'nin CEA ve CA 19-9'dan bağımsız artışının ise kanser varlığı dışında başlıca böbrek fonksiyonundan etkilenmesi nedeniyle olabileceği düşünüldü.

Yüksek serum sistatin $C$ düzeyi vücudun artmış sistein proteaz aktivitesine yetersiz yanıtını yansıtıyor olabilir. Ayrıca kanserli hastalarda proteinazların posttranslasyonel modifikasyonları inhibitör aktiviteye yanıtlarını değiştirebilir. Donahue ve ark. (30) KRK'de katepsin B'nin glikozilasyonunda farklılıklar izlendiğini bildirmişlerdir. Diğer risk faktörlerine göre düzeltme yapıldığında kontrol grubuna göre sistatin C'nin yüksek bulunma intimali üzerinde KRK grubunda bulunmanın daha fazla etkili olduğu görülmüştür (Tablo 3). İçerdiği olgu sayısının nispeten az ve hastalık evrelerine göre gruplandırılmamış olması çalışmamızın bir diğer dezavantajını oluşturmaktadır. KRK grubunda bulunmanın serum sistatin $C$ düzeyi üzerine etkisi bu grupta bulunan olguların rastlantısal olarak hastalığın belirli evrelerinde yoğunlaşması ya da KRK'de sistatin C, katepsin B ve TGF- $\beta$ etkileşimlerinin daha yoğun izlenmesi nedeniyle ekspresyonunun daha belirgin artışı olabilir.

Sonuç olarak, KRK ve mide kanseri hastalarında serum sistatin $C$ düzeyinin incelendiği çalışmamızda sistatin $C$ yüksekliği üzerinde sırasıyla; kreatinin düzeyi ve kanser hastası olmanın etkili olduğu bulunmuştur. Sistatin C'nin CEA ve CA 19-9'dan bağımsız artışının kanser varlığı dışında başlıca böbrek fonksiyonundan etkilenmesi nedeniyle olabileceği düşünüldü. Mide veya kolorektal kanserli olgularda böbrek fonksiyonlarını değerlendirmede serum sistatin $C$ düzeyi kullanılacaksa kansere bağıl artışlar açısından dikkatli olunmalıdır. Hastalık yaygınlığına göre sınıflandırılmış daha geniş hasta grupları ve GFH için referans yöntemin kullanılacağı bir çalışma ile serum sistatin $C$ düzeyindeki artışın nedeni daha iyi ortaya konulabilir.

\section{Açıklamalar}

Uzmanlık tezinden üretilen bu çalışmanın yayına hazırlanmasından önce vefat eden danışman hocamız Dr Yüksel Koca'ya katkıları için sonsuz teşekkürlerimizi sunarız.

Etik onam: Bu çalışma T.C. Sağlık Bakanlığı Ankara Numune Eğitim ve Araştırma Hastanesi'nin 25/01/2012 tarih ve 2012-302 numaralı etik kurul kararıyla onaylanmıştır.

\section{Kaynaklar}

1. Cancer Fact Sheet [on the Internet]. World Health Organization. [updated 12 September 2018; cited 31 January 2020]. Available from: https://www.who.int/news-room/fact-sheets/detail/cancer.

2. Talieri M, Papadopoulou S, Scorilas A, Xynopoulos D, Arnogianaki N, Plataniotis $G$, et all. Cathepsin B and cathepsin D expression in the progression of colorectal adenoma to carcinoma. Cancer Lett. 2004;205(1):97-106.

3. Chen S, Dong H, Yang S, Guo H. Cathepsins in digestive cancers. Oncotarget. 2017;8(25):41690-41700.

4. Turk V, Stoka V, Vasiljeva O, Renko M, Sun T, Turk B, et all. Cysteine cathepsins: from structure, function and regulation to new frontiers. Biochim Biophys Acta. 2012;1824(1):68-88.

5. George JA, Gounden V. Novel glomerular filtration markers. Adv Clin Chem. 2019;88:91-119.

6. Nomura $T$, Katunuma N. Involvement of cathepsins in the invasion, metastasis and proliferation of cancer cells. J Med Invest. 2005;52(12):1-9.

7. Kos J, Nielsen HJ, Krasovec M, Christensen IJ, Cimerman N, Stephens RW, et all. Prognostic values of cathepsin B and carcinoembryonic antigen in sera of patients with colorectal cancer. Clin Cancer Res. 1998;4(6):1511-6.

8. Zeng Q, Zhao Y, Yang Y, Chen XX, Wang G, Zhang P, et all. Expression of Cystatin $C$ in human stomach neoplasms. Mol Med Rep. 2010;3(4):607-11.

9. Saleh Y, Sebzda T, Warwas M, Kopec W, Ziólkowska J, Siewinski M. Expression of cystatin $\mathrm{C}$ in clinical human colorectal cancer tissues. J Exp Ther Oncol. 2005;5(1):49-53.

10. Bierie B, Moses HL. Tumour microenvironment: TGF $\beta$ : the molecular Jekyll and Hyde of cancer. Nat Rev Cancer. 2006;6(7):506-20.

11. Sokol JP, Schiemann WP. Cystatin C Antagonizes Transforming Growth Factor $\beta$ Signaling in Normal and Cancer Cells. Mol Cancer Res. 2004;2(3):183-95.

12. Kos J, Stabuc B, Cimerman N, Brünner N. Serum cystatin C, a new marker of glomerular filtration rate, is increased during malignant progression. Clin Chem. 1998;44(12):2556-7.

13. Nakai K, Kikuchi M, Fujimoto K, Kaneko Y, Omori S, Nakai K, et all. Serum levels of cystatin $\mathrm{C}$ in patients with malignancy. Clin Exp Nephrol. 2008;12(2):132-9.

14. Zhai H, Huang J, Yang C, Fu Y, Yang B. Serum CEA and CA19-9 Levels are Associated with the Presence and Severity of Colorectal Neoplasia. Clin Lab. 2018;64(3):351-6.

15. Shin JK, Kim HC, Lee WY, Yun SH, Cho YB, Huh JW, et all. High preoperative serum CA 19-9 levels can predict poor oncologic outcomes in colorectal cancer patients on propensity score analysis. Ann Surg Treat Res. 2019;96(3):107-15.

16. Saito $H$, Kono $Y$, Murakami $Y$, Kuroda $H$, Matsunaga $T$, Fukumoto $Y$, et all. Influence of prognostic nutritional index and tumor markers on survival in gastric cancer surgery patients. Langenbeck Arch Surg. 2017;402(3):501-7.

17. Bodnar L, Wcislo GB, Smoter M, Gasowska-Bodnar A, Stec R, Synowiec $A$, et all. Cystatin $C$ as a parameter of glomerular filtration rate in patients with ovarian cancer. Kidney Blood Press Res. 2010;33(5):360-7.

18. Strojan P, Budihna M, Šmid L, Svetic B, Vrhovec I, Kos J, et all. Prognostic significance of cysteine proteinases cathepsins $B$ and $L$ and their endogenous inhibitors stefins $A$ and $B$ in patients with squamous cell carcinoma of the head and neck. Clin Cancer Res. 2000;6(3):105262.

19. Kos J, Lah TT. Cysteine proteinases and their endogenous inhibitors: target proteins for prognosis, diagnosis and therapy in cancer. Oncol Rep. 1998;5(6):1349-61.

20. McPherson RA, Pincus MR. Henry's clinical diagnosis and management by laboratory methods. 22nd ed. Philadelphia: Elsevier Saunders, 2011:480-506.

21. Herszényi L, Farinati F, Cardin R, István G, Molnár LD, Hritz I, et all. 
Tumor marker utility and prognostic relevance of cathepsin B, cathepsin $L$, urokinase-type plasminogen activator, plasminogen activator inhibitor type-1, CEA and CA 19-9 in colorectal cancer. BMC Cancer. 2008;8:194.

22. Štabuc B, Vrhovec L, Štabuc-Šilih M, Cizej TE. Improved prediction of decreased creatinine clearance by serum cystatin C: use in cancer patients before and during chemotherapy. Clin Chem. 2000;46(2):1937.

23. Kleber M, Cybulla M, Bauchmüller K, Ihorst G, Koch B, Engelhardt $M$. Monitoring of renal function in cancer patients: an ongoing challenge for clinical practice. Ann Oncol. 2007;18(5):950-8.

24. Kos J, Krašovec M, Cimerman N, Nielsen HJ, Christensen IJ, Brünner N. Cysteine proteinase inhibitors stefin A, stefin B, and cystatin $C$ in sera from patients with colorectal cancer: relation to prognosis. Clin Cancer Res. 2000;6(2):505-11.

25. Grubb AO. Cystatin C-properties and use as diagnostic marker. Adv Clin Chem. 2000;35:63-99.

26. Massey D. Commentary: clinical diagnostic use of cystatin C. J Clin Lab Anal. 2004;18(1):55-60.

27. Kos J, Stabuc B, Schweiger A, Krasovec M, Cimerman N, KopitarJerala $N$, et all. Cathepsins $B, H$, and $L$ and their inhibitors stefin $A$ and cystatin $C$ in sera of melanoma patients. Clin Cancer Res. 1997;3(10):1815-22.

28. Kos J, Werle B, Lah T, Brunner N. Cysteine proteinases and their inhibitors in extracellular fluids: markers for diagnosis and prognosis in cancer. Int J Biol Markers. 2000;15(1):84-9.

29. Zore I, Krasovec M, Cimerman N, Kuhelj R, Werle B, Nielsen HJ, et all. Cathepsin B/cystatin $\mathrm{C}$ complex levels in sera from patients with lung and colorectal cancer. Biol Chem. 2001;382(5):805-10.

30. lacobuzio-Donahue CA, Shuja S, Cai J, Peng P, Murnane MJ. Elevations in cathepsin $B$ protein content and enzyme activity occur independently of glycosylation during colorectal tumor progression. J Biol Chem. 1997;272(46):29190-9. 